\title{
Diskursus Kebenaran Berita Berdasarkan Undang-Undang Nomor 40 Tahun 1999 Tentang Pers Dan Kode Etik Jurnalistik
}

\author{
Taufik Hidayat Lubis, Ismail Koto
}

\author{
Fakultas Hukum, Universitas Muhammadiyah Sumatera Utara \\ JL. Kapten Mukhtar Basri No 3 Medan 20238 \\ Telp: (061) 6622400, Fax: (061) 6623474, 6631003) \\ Email: taufikhidayat@umsu.ac.id, ismailkoto602@gmail.com
}

\author{
Naskah Diterima: 05-02-2020, Direvisi: 29-06-2020, Disetujui: 06-07-2020, Diterbitkan: 07-07-2020 \\ DDI: https://dai.org/10.30596/dll.v5i2.4169
}

\begin{abstract}
Abstrak
Kebenaran suatu berita bukanlah kebenaran absolut karena kebenaran dalam berita dapat berubah-ubah, oleh karena itu kebenaran yang dimaksud dalam suatu berita adalah kebenaran yang merujuk kepada fakta di lapangan atas peristiwa yang tejadi. Untuk memastikan bagaimana kebenaran itu terbentuk maka terdapat ketentuan yang harus diikuti oleh para jurnalis sehingga berita tersebut dapat dikatakan menjadi suatu kebenaran. Atas hal tersebut diangkatlah suatu permasalahan bagaimana suatu kebenaran dalam berita dapat terbentuk sehingga kebenarannya dapat dipertanggungjawabakan yang didasari pada Undang-Undang Nomor 40 Tahun 1999 tentang Pers dan Kode Etik Jurnalistik. Berdasarkan penelitian yang ada suatu kebenaran dalam berita haruslah merujuk kepada Undang-Undang Nomor 40 Tahun 1999 tentang Pers dan Kode Etik Jurnalistik. Kebenaran dalam berita haruslah terbentuk yang didasari Pasal 1 angka 1 Undang-Undang Nomor 40 Tahun 1999 tentang Pers, “...mencari, memperoleh, memiliki, menyimpan, mengolah, dan menyampaikan informasi..." dan selanjutnya untuk mendukung kegiatan jurnalistik tersebut para jurnalis haruslah memiliki apa yang sesuai dalam Pasal 1 Peraturan Dewan Pers Nomor:6/Peraturan-DP/V/2008 tentang Pengesahan Surat Keputusan Dewan Pers Nomor 03/SK-DP/III/2006 tentang Kode Etik Jurnalistik Sebagai Peraturan Dewan Pers, disebutkan bahwa "Wartawan Indonesia bersikap independen, menghasilkan berita yang akurat, berimbang dan tidak beritikad baik".
\end{abstract}

\section{Kata Kunci: Berita, Kebenaran, Fakta}

Abstract

The truth of news is not absolute because the truth can change, therefore the truth refers to the facts occurred. To ensure how the truth is formed, there are provisions that journalists must follow so that the news can be said to be truth. On this matter raised a problem of how a truth in the news can be formed, it can be accounted for based on Law Number 40 of 1999 concerning the Press and Journalistic Code of Ethics. Based on the research, truth in the news must refer to Law Number 40 of 1999 concerning the Press and Journalistic Code of Ethics. Truth in the news must be formed based on Article 1 number 1 of Law Number 40 of 1999 concerning the Press, "... seeking, obtaining, possessing, storing, processing, and conveying information ..." and furthermore to support journalistic activities journalists must possess what in accordance with Article 1 Press Council Regulation Number: 6/Regulation-DP/V/2008 concerning Ratification of Press Council Decree Number 03/SK-DP/III/2006 concerning Journalistic Code of Ethics As a Press Council Regulation, it was stated that "Indonesian Journalists independent, produce accurate, balanced and not in good faith news".

Keywords: News, Truth, Fact

Diskursus Kebenaran Berita... (Taufik Hidayat Lubis, Ismail Koto) 231 


\section{PENDAHULUAN}

Pada dasarnya mendapatkan informasi adalah salah satu keinginan yang paling mendasar bagi setiap manusia. Hal ini dikarenakan dengan mendapatkan informasi setiap orang dapat terbantu dalam mengembangkan potensi di dalam dirinya. Sebegitu pentingnya suatu informasi, seorang pebisnis yang bernama I Ketut Dede Yudantara (2006, h. 48) mengatakan bahwa pemacu peningkatan skill individu dapat dilakukan dengan banyak membaca dengan dibantu mendengarkan berita-berita radio, televisi, internet, komputer dan sebagainya. I Ketut Dede Yudantara (2006, h. 48) juga menjelaskan bahwa apabila ketertinggalan informasi, maka hanya rasa pesimis yang akan muncul. Keberanian tumbuh dari kesadaran diri karena merasa mengetahui, merasa mampu dan mengerti tentang masalah. Oleh karena itu dengan mendapatkan informasi atas segala pengetahuan menjadi sangatlah penting.

Selain itu pula dengan mendapatkan informasi, masyarakat akan terbantu dalam pemenuhan kebutuhan hidupnya. Sebagai salah satu contoh seperti berita perkiraan cuaca. Berita perkiraan cuaca sangat bermanfaat bagi perusahaan yang menjalankan usaha di bidang perhubungan seperti pesawat, kapal laut maupun darat. Manfaat informasi bagi kehidupan manusia yang tidak hanya sebatas memberikan manfaat untuk menumbuh kembangkan potensi manusia untuk menjadi lebih baik, akan tetapi juga untuk melengkapi kebutuhan kehidupan manusia. Oleh karenanya sifat dasar atas hak untuk mengetahui mendapatkan informasi adalah hak yang tidak dapat dibatasi dan harus diberikan sebesar-besarnya bagi setiap warga.

Saat ini masyarakat sudah sangat dimudahkan untuk memperoleh informasi setiap harinya, hanya dengan mengakses aplikasi media di internet atau hanya dengan memilih salah satu siaran berita di saluran televisi maka siapa pun sudah dapat memilih pelbagai informasi yang diinginkan. Ini dapat terjadi disebabkan adanya kemajuan teknologi yang telah mempercepat penyebaran dan peredaran informasi. Maka tidak heran apabila suatu kejadian dari tempat yang sangat jauh dan tidak mudah dijangkau, namun masyarakat dalam waktu singkat dapat mengetahui berita terkait atas apa yang sedang terjadi di tempat tersebut.

Perkembangan teknologi memang tidak dapat dibatasi, oleh karena itu sikap bijak dalam penyesuaian atas perkembangan tersebut sangat dibutuhkan. Hal inilah yang dilakukan oleh beberapa pers mainstream yang pada mulanya berkembang di media cetak, namun untuk ikut bersaing dalam dunia informasi yang semakin pesat maka keharusan untuk aktif dalam media elektronik khususnya di media online harus diikuti. Namun informasi atau berita yang disebarkan oleh pers secara online pun menyisakan suatu permasalahan, permasalahan itu muncul dari konsep cepat atau akurat.

Sebenarnya tidak ada perbedaan antara berita yang dimuat secara cetak ataupun online, karena kedua-duanya adalah berita yang harus tetap disajikan dengan prinsip kebenaran. Namun pada faktanya pers yang menyajikan berita secara online kerap membuat berita menjadi tidak akurat yang pada akhirnya jauh dari kebenaran. Salah satu contoh yang dapat diambil adalah berita terkait kasus tertangkap tangannya mantan Ketua Mahkamah Konstitusi (MK), Akil Mochtar di awal Oktober 2013. Berita yang muncul pun salah satunya dari media online memberitakan bahwa Akil Mochtar adalah orang yang bersalah. Padahal putusan dari pengadilan sama sekali belum ada (Juditha, 2013, h. 146). Pada tanggal 24 Mei 2001 terdapat situs media online yang memberitakan Wimar Witoelar meninggal dunia. Namun pada faktanya Wimar sama sekali pada saat itu tidak meninggal dunia. Faktanya adalah Wimar dibawa ke 
rumah sakit karena mendapat serangan stroke (Margianto \& Syaefullah, 2014, h. 39). Bahkan yang cukup menghebohkan di tahun 2018 lalu, banyak media online yang sudah dikenal oleh masyarakat banyak memberitakan penganiayaan yang dialami oleh Ratna Sarumpaet yang pada faktanya berita penganiayaan tersebut adalah tidak benar, bahwa atas nama kecepatan pemberitaan di media secara online, seolah-olah kebenaran berita menjadi tidak begitu penting karena yang terpenting adalah aktualitas berita (Muhammad Ridlo, 10 Oktober 2018, "HatiHati dengan Berita Bohong”, Diambil dari https://dewanpers.or.id/publikasi/opini_detail/166/Hati-hati_Dengan_Berita_Bohong).

Jurnalisme online selalu menjadi sorotan karena sering kali dianggap tidak mengedepankan objektifitas (akurasi, fairliness, kelengkapan dan imparsialitas) berita hanya untuk mengejar kecepatan penyebaran informasi. Hal inilah yang kerap menjadi masalah, di satu sisi media online sangat memungkinkan melakukan penyebaran informasi jauh lebih cepat dari pada media konvensional namun di sisi lain kecepatan mengorbankan prinsip-prinsip dasar jurnalisme di antaranya akurasi berita (Juditha, 2013, h. 146).

Tidak dinafikkan apabila masyarakat ingin mendapatkan berita yang cepat akan tetapi keakuratan dan kebenaran suatu berita juga lebih penting. Apabila suatu berita mengandung kebohongan, maka efeknya ada pada si penerima berita. Awalnya si pembaca berita tidak peduli dengan berita tersebut, akan tetapi karena diberitakan secara terus-menerus dan berulang maka akan timbul kepercayaan bahwa berita tersebut benar. Pada akhirnya si pembaca berita disesatkan atas berita bohong yang dibaca atau didengarnya.

Tugas penting seorang jurnalis bukan hanya bisa menghasilkan sebuah berita yang menarik, akan tetapi juga dapat menghasilkan berita yang bermanfaat dan dapat digunakan dalam kehidupan sehari-hari. Tugas penting itu dimulai dari proses pengumpulan informasi, pengolahan informasi dan penyampaian informasi. Kejujuran atas pengambilan informasi yang benar sangatlah penting karena akan menghasilkan manfaat bagi setiap diterbitkan, akan tetapi apabila sebuah informasi yang diambil secara tidak benar bahkan mengarah kepada sebuah kebohongan maka berita yang dihasilkan akan menyesatkan bagi pembacanyan dan pastinya tidak memberikan bermanfaat.

Dilema jurnalis adalah ketika harus memilih antara kecepatan atau akurasi berita yang mengakibatkan adanya kebenaran berita. Di satu sisi berita harus cepat disampaikan kepada masyarakat, di sisi lain berita yang disampaikan haruslah memiliki akurasi dan ketepatan berita sehingga tidak menimbulkan kebohongan. Kecepatan dalam penyebaran berita tidak selalu identik dengan berita palsu, akan tetapi akurasi dan ketepatan beritanya tidak sebaik dari berita yang disampaikan melalui media cetak.

Berita yang disampaikan secara online dapat tercipta setiap jamnya atau bahkan lebih cepat, namun berita yang disampaikan secara cetak tercipta paling cepat setiap 24 jam sekali. Dari perhitungan waktu saja dapat dilihat bagaimana proses pengolahan media cetak memiliki waktu yang lebih lama dibandingkan dengan media online, sehingga atas waktu yang lama tersebut pengolahan benar-benar dilakukan karena memiliki waktu yang lebih banyak, sementara itu dalam media online, terbitan berita bersaing pada kecepatan penyebaran informasi sehingga atas waktu yang singkat tersebut pengolahan informasinya akan menyisakan permasalahan terkait akurasi berita. Namun bukan berarti media cetak tidak pernah menyebarkan berita bohong karena di tahun 2019 lalu ketika Harian Indopos dan Media Siber indopos.co.id dinyatakan telah melanggar 5 Pasal yang ada di dalam Kode Etik Jurnalistik yang 
salah satunya adalah pada Pasal 4 yaitu karena bohong dan fitnah. Fakta yang ada tidak memberikan jaminan kalau media massa cetak jauh lebih baik dari pada media online, akan tetapi yang pasti setiap media massa baik online, elektronik maupun cetak harus mengedepankan kebenaran atas suatu berita.

Masyarakat bukanlah objek pers karena apabila kedudukannya sebagai objek maka yang akan terjadi hilanglah tanggung jawab pers atas kebenaran di dalamnya. Ibarat hubungan antara guru dan murid maka masyarakat dengan pers juga memiliki hubungan berdasarkan perannya masing-masing (Harisman, 2020, h. 85). Masyarakat bukanlah objek yang hanya menjadi target pasar untuk mendapatkan keuntungan semata akan tetapi masyarakat seharusnya diperlakukan selayaknya sebagai subjek manusia yang membutuhkan banyak informasi sehingga apa yang akan disampaikan pers adalah sesuatu yang tidak hanya sekedar hiburan semata namun juga edukasi dalam hal mengisi kebutuhan kehidupan manusia. Berdasarkan hal tersebut di atas tulisan ini mengkaji mengenai bagaimana suatu kebenaran dalam berita dapat terbentuk sehingga kebenarannya dapat dipertanggungjawabakan yang didasari pada Undang-Undang Nomor 40 Tahun 1999 tentang Pers dan Kode Etik Jurnalistik.

\section{METODE PENELITIAN}

Suatu penelitian tidak dapat dikatakan penelitian apabila tidak memiliki metode penelitian karena tujuan dari penelitian adalah untuk mengungkapkan suatu kebenaran secara sistematis, metodologis dan konsisten (Ali, 2011, h. 17) sebagaimana penelitian hukum yang merupakan suatu proses untuk menemukan aturan hukum, prinsip-prinsip hukum, maupun doktrin-doktrin hukum yang berguna untuk menjawab isu hukum (Ibrahim, 2008, h. 282). Disebabkan adanya keragaman metode penelitian, maka perlu dikategorikan metode penelitian yang digunakan dalam tesis ini. Jenis metode penelitian yang digunakan dalam tulisan ini adalah penelitian yuridis normatif. Penelitian yuridis normatif adalah penelitian yang digunakan untuk mengkaji penerapan kaedah-kaedah atau norma-norma hukum (Ibrahim, 2008, h. 282), sedangkan menurut Zainuddin Ali (2011, h. 24) penelitian yuridis normatif membahas doktrin-doktrin atau asas-asas dalam ilmu hukum. Berdasarkan kegunaannya, jenis metode penelitian yuridis normatif berguna untuk mengetahui atau mengenal apakah dan bagaimanakah hukum positifnya mengenai suatu masalah tertentu dan juga dapat menjelaskan atau menerangkan kepada orang lain apakah dan bagaimanakah hukumnya mengenai peristiwa atau masalah yang tertentu (Hartono, 1994, h. 140).

Penelitian ini menggunakan prosedur dalam pengumpulan datanya yaitu yang salah saatunya adalah penelusuran literatur, hukum buku-buku dan lainnya (Rahmi, 2019, h. 145) yang berhubungan dengan berita yang memiliki kebenaran yang didasarkan pada UndangUndang Nomor 40 Tahun 1999 tentang Pers dan Kode Etik Jurnalistik.

\section{PEMBAHASANDAN ANALISIS Pengertian Berita}

Secara pengertian berita adalah fakta atau peristiwa yang terjadi di lapangan. Fakta itu diliput, ditulis dan diedit oleh jurnalis baru kemudian disebarkan melalui media massa. Karakteristik yang menonjol adalah berita bukanlah hasil karya sentuhan tangan wartawan saja, tetapi beberapa wartawan yang bekerja sama secara berjenjang. Ada reporter yang meliputi ke lapangan, adapula redaktur yang mengedit berita di kantor redaksi media (M. Fikri AR, 2016, 
h. 115). Menurut Jani Yosef berita adalah laporan terkini tentang fakta atau pendapat yang penting atau menarik bagi khalayak dan disebarluaskan melalui media massa (Khoirul Muslimin, 2019, h. 7). Sedangkan menurut Hoetea Soehot berita adalah keterangan mengenai peristiwa atau isi pernyataan manusia (Khoirul Muslimin, 2019, h. 7. Menurut Khoirul Muslimin sendiri $(2019$, h. 7$)$ berita adalah laporan mengenai kejadian atau peristiwa penting dan menarik bagi khalayak pembacanya.

Turner Cathledhe dari New York Timesmenjelaskan bahwa berita memiliki pengertian segala sesuatu yang tidak Anda ketahui pada hari kemarin (Fachruddin, 2017, h. 49). Mitchel V. Chantley mendefinisikan berita adalah laporan yang tepat waktu mengenai fakta atau opini yang memiliki daya Tarik atau hal penting atau kedua-keduanya bagi masyarakat luas (Fachruddin, 2017, h. 49).JB Wahyudi menyebutkan bahwa berita adalah laporan tentang peristiwa atau pendapat yang memiliki nilai penting, menarik bagi sebagian khalayak, masih baru dan dipublikasikan secara luas melalui media massa periodik (Andi Fachruddin, 2017, h. 49).

Di dalam buku yang berjudul Keterampilan Pers dan Jurnalistik Berwawasan Jender karya Tahrun, Houtman, dkk (2019, h. 67) menyebutkan bahwa berita terdiri beberapa definisi yaitu:

1. Berita adalah informasi hangat yang disajikan kepada umum mengenai apa yang sedang terjadi

2. Berita adalah suatu yang menarik perhatian sebagian besar komunikasi

3. Berita adalah informasi mengenai peristiwa atau ide yang menarik perhatian dan mempengaruhi kehidupan manusia

4. Berita adalah sesuatu yang luas biasa

Gaye Tuchman dalam bukunya yang berjudul Making News (Rizki, 2016, h. 55) menyebutkan bahwa berita merupakan konstruksi realitas sosial. Berita yang disajikan media massa tidak sepenuhnya merepresentasikan fakta-fakta atau kenyataan yang sebenarnya dan apa adanya. Berita adalah produk dari sebuah usaha/proses menyusun fakta-fakta menjadi sesuatu yang menarik untuk dikonsumsi. Tuchmn menekankan bahwa berita adalah sekutu bagi lembaga-lembaga yang berlegitimasi dan bahwa berita juga melegitimasi status quo. Menurut Wahyu Wibowo, berita adalah "Informasi terkini mengenai sesuatu yang telah terjadi atau mengenai sesuatu yang belum diketahui sebelumnya" (2009, h. 13).

Beberapa pendapat di atas dalam mendefinisikan berita tidak lepas dengan kata 'fakta' dan apabila dihubungkan berdasarkan maknanya akan berkorelasi dengan real-nya atau realitas suatu kenyataan terhadap sesuatu keadaan. Fakta-fakta tersebut dibangun atau dikonstruksikan dalam bentuk sebuah laporan yang kemudian disampaikan kepada khalayak ramai dalam bentuk berita. Pemahaman isi berita menjadi kondisional karena dipengaruhi seberapa luas pengetahuan pembaca atau pendengarnya, karena apabila berita itu bersumber dari media massa yang tidak kredibel pastinya kemungkinan besar berita itu akan menyesatkan, namun apabila media massa itu memiliki kredibilitas dalam kegiatan jurnalistiknya maka pastinya berita yang disampaikan dapat menjadi dasar untuk memahami fakta realitas tersebut.

Tidak semua fakta dapat 'layak' dijadikan berita karena hanya fakta yang penting, menarik dan aktual-lah suatu berita itu layak untuk dijadikan berita dan apa yang dimaksud oleh Jani Yosef tersebut berikut penjelasannya (Muslimin, 2019, h. 7):

1. Penting 
Penting memiliki arti orang penting (orang ternama) dan peristiwa penting. Media sering mengangkat peristiwa atau kegiatan yang dialami oleh orang penting menjadi sebuah berita

2. Menarik

Menarik bagian kriteria umum nilai berita maupun acuan yang dapat digunakan oleh para jurnalis, yaitu pada wartawan dan editor untuk menyeleksi berita yang layak untuk disajikan atau terbit.

3. Aktual

Unsur aktual sangatlah penting dalam kegiatan jurnalistik, khususnya dalam proses produksi berita 'aktualisasi'. Berkembangnya teknologi saat ini, menyebabkan aktualitas memiliki tingkatan aktualnya mulai dari paling aktual, cukup aktual dan kurang aktual.

Berita yang disampaikan oleh berita tidak selamanya menjadi layak atau menarik untuk didengar atau dibaca karena terkadang terdapat berita yang memang jauh dari kata menarik sehingga tidak layak untuk dijadikan rujukan. Menarik atau tidak menariknya berita yang disampaikan oleh media massa dikarenakan lima faktor sebagai berikut (Rizki, 2016, h. 55-57):

1. Level individual. Pada level ini berhubungan dengan latar belakang professional dari pengelola media. Level individual melihat bagaimana pengaruh aspke-aspek personal dari pengelola media mempengaruhi pemberitaan yang ditampilkan kepada khalayak. Latar belakang individu ini dikarenakan beberapa hal yaitu; jenis kelamin, umur atau agama, sedikit banyaknya mempengaruhi apa yang ditampilkan media

2. Level rutinitas. Pada level ini berhubungan dengan rutinitas media dengan mekanisme dan proses penentuan berita. Setiap media umumnya mempunyai ukuran tersendiri tentang apa yang disebut dengan berita, apa ciri-ciri berita yang baik atau apa kriteria kelayakan berita. Ukuran tersebut adalah rutinitas yang berlangsung setiap hari dan menjadi prosedur standar bagi pengelola media yang berada di dalamnya. Rutinitas media ini banyak juga berkaitan dengan mekanisme bagaimana berita dibentuk, misalnya; bagaimana redaksi dilaksanakan dan atau bagaimana menentukan budget.

3. Level organisasi. Level organisasi berhubungan dengan struktur organisasi yang secara hipotesis mempengaruhi pemberitaan. Pengelola media dan wartawan bukan orang yang tunggal yang ada dalam organisasi berita. Sebaliknya hal ini hanya bagian kecil dari organisasi media itu sendiri. Masing-masing komponen dalam organisasi media bisa jadi mempunyai kepentingan sendiri-sendiri.

4. Level ekstra media. Level ini berhubungan dengan faktor lingkungan di luar media yang mempengaruhi pemberitaan, yaitu:

a. Sumber berita. Sumber berita dipandang bukan pihak yang netral yang memberikan informasi apa adanya. Ia juga memiliki kepentingan untuk mempengaruhi media dengan berbagai alasan; memenangkan opnini publik atau memberi citra tertentu kepada khalayak. Sebagai pihak yang memiliki kepentingan, sumber berita tentu memberlakukan politik pemberitaan.

b. Sumber penghasilan media. Sumber penghasilan media bisa berupa iklan, pembeli/pelanggan media. Kadangkala media harus kompromi dengan sumber daya yang menghidupinya.

5. Level ideologi. Ideologi di sini diartikan sebagai kerangka berpikir atau kerangka referensi tertentu yang dipakai oleh individu untuk melihat realitas dan bagaimana mereka menghadapinya. Berbeda dengan elemen sebelumnya yang tampak konkret, level ideology 
ini abstrak. Ia berhubungan dengan konsepsi atau posisi seseorang dalam menafsirkan realitas. Pada level ideologi lebih melihat kepada yang berkuasa di masyarakat dan bagaimana media turut menentukannya.

Berbagai macam cara berita dapat dibentuk dan berbagai macam cara isi berita dapat dipengaruhi akan tetapi suatu berita tidak akan pernah kehilangan makna dari realitasnya apabila memiliki unsur-unsur atau rumusan umum penulisan berita yang dikenal dengan $5 \mathrm{~W}+$ $1 \mathrm{H}$, what (apa yang terjadi), where (di mana hal itu terjadi), when (kapan peristiwa itu terjadi), who (siapa yang terlibat dalam kejadian itu), why (kenapa hal itu terjadi) dan how (bagaimana peristiwa itu terjadi). Dan proses dalam pengumpulan $5 \mathrm{~W}+1 \mathrm{H}$ tersebut dilakukan dalam bentuk kegiatan jurnalistik yang diatur sesuai dengan Pasal 1 angka 1 Undang-Undang Nomor 40 Tahun 1990 tentang Pers. Selain untuk mengkonstruksikan berita menjadi suatu kebenaran, kegiatan jurnalistik yang dimaksud dalam Pasal 1 angka 1 Undang-Undang Nomor 40 Tahun 1999 tentang Pers juga memberikan kepastian hukum kepada para jurnalis dalam melakukan kegiatan jurnalistik karena dengan berpedoman dari aturan yang ada akan memberikan suatu keadaan yang pasti dan sesuai dengan ketetapan suatu hukum (Rahmat Ramadhani, 2017, h. 142). Dengan mengikuti aturan yang ada para jurnalis akan merasa aman dan nyaman, sebab tidak ada keraguan atau ketidakpastian dalam menjalankan kegiatan jurnalistik tersebut.

\section{Terbentuknya Kebenaran Atas Berita}

Hak untuk mendapatkan informasi secara konstitusi telah diatur di dalam Pasal $28 \mathrm{~F}$ Undang-Undang Dasar 1945 "Setiap orang berhak untuk berkomunikasi dan memperoleh informasi untuk mengembangkan pribadi dan lingkungan sosialnya, serta berhak untuk mencari, memperoleh, memiliki, menyimpan, mengolah dan menyampaikan informasi dengan menggunakan segala jenis saluran yang tersedia", selain itu pula hak mendapatkan informasi juga diatur dalam Pasal 14 Ayat 1 dan 2 Undang-Undang Nomor 39 Tahun 1999 tentang Hak Asasi Manusia, "Setiap orang berhak untuk berkomunikasi dan memperoleh informasi yang diperlukan untuk mengembangkan pribadinya dan lingkungan sosialnya" dan "setiap orang berhak untuk mencari, memperoleh, memiliki, menyimpan, mengolah, dan menyampaikan informasi dengan menggunakan segala jenis sarana yang tersedia." Selaras dengan itu pers nasional hadir sebagai media informasi yang bermakna sebagai pemberi informasi kepada masyarakat sehingga hak-hak masyarakat tersebut dapat terpenuhi, hal ini sesuai yang diatur dalam Pasal 3 Undang-Undang Nomor 40 tahun 1999 tentang Pers.

Mendapatkan informasi yang telah diatur di dalam Pasal 28 F Undang-Undang Dasar 1945 dan Pasal 14 Ayat 1 dan 2 Undang-Undang Nomor 39 Tahun 1999 tentang Hak Asasi Manusia tidak mengkhususkan kepada satu konteks tentang suatu hal tertentu namun juga tidak membatasi tentang suatu hal tertentu, dengan demikian mendapatkan informasi yang dimaksud dapat dalam bentuk apapun termasuk mendapatkan informasi yang disampaikan oleh pers ke publik. Dasar untuk mendapatkan informasi yang dimiliki masyarakat tidak lepas dari dasar adanya rasa ingin mengetahui oleh karena itu dalam Pasal 6 huruf a Undang-Undang Nomor 40 Tahun 1999 tetang Pers menyebutkan "Pers nasional melaksanakan peranan memenuhi hak masyarakat untuk mengetahui." Atas dasar inilah antara masyarakat dan pers tidak dapat dipisahkan karena hubungan yang terbentuk itu merupakan hubungan yang timbal balik.

Informasi atau berita merupakan salah satu objek utama dalam kegiatan pers karena memang informasilah yang menjadi sasaran utama nilai jualnya pers namun perlu diketahui 
juga bahwa berita yang disampaikan oleh pers tersebut juga harus dapat dinilai apakah mengandung kebenaran atau tidak karena melihat banyaknya berita-berita yang beredar saat ini mengandung ketidakbenaran atau hoaks sehingga masyarakat tidak mampu lagi untuk melihat mana berita yang benar dan mana berita yang tidak benar. Munculnya suatu keadaan di mana masyarakat harus mampu menilai mana saja berita yang tidak benar, mantan Ketua Dewan Pers Yosep Adi Prasetyo menjelaskan bahwa agar tidak terpengaruh dengan berita-berita bohong maka harus dapat dikenali ciri-ciri dari berita hoaks itu yang mana sebagai berikut (Dedy (5 Oktober 2017). Dewan Pers Beberkan Ciri-Ciri Berota Hoax. Diambil dari https://dewanpers.or.id/berita/detail/875/Dewan-Pers-Beberkan-Ciri-Ciri-Berita-Hoax):

1. Berita itu dapat mengakibatkan kecemasan, permusuhan dan kebencian pada masyarakat. Pada umumnya berita-berita seperti ini memancing perdebatan sehingga pada akhirnya saling bermusuhan

2. Ketidakjelasan sumber beritanya. Berita-berita tidak benar pada umumnya berasal dari pemberitaan yang tidak atau sulit untuk terverifikasi

3. Pemberitaan tidak seimbang dan cenderung menyudutkan pihak tertentu

4. Bermuatan fanatisme atas nama ideologi. Judul dan pengantarnta provokatif, memberikan penghakiman bahkan penghukuman tetapi menyembunyikan fakta dan data

Keempat ciri-ciri berita hoaks yang dijelaskan oleh Kedua Dewan Pers tersebut bukanlah bersifiat kolektif atau dimaknai berita tersebut harus terdiri dari keempat ciri-ciri di atas akan tetapi apabila salah satu saja dari ciri-ciri itu ada dalam suatu berita maka berita tersebut dapat terindikasi berita berita hoaks. Namun bukanlah suatu kemutlakan pula apabila ada berita yang mengandung salah satu saja ciri-ciri berita di atas pasti berita hoaks. Ketua Dewan Pers menjelaskan ciri-ciri di atas adalah sebagai salah satu cara untuk melihat apakah berita tersebut benar atau tidak sehingga apabila ada berita yang mengandung ciri-ciri di atas maka masyarakat haruslah teliti, klarifikasi kebenaran berita dan verifikasi berita dengan cara membandingkannya dengan berita yang lain. Dedy (5 Oktober 2017). Dewan Pers Beberkan Ciri-Ciri Berota Hoax. Diambil dari https://dewanpers.or.id/berita/detail/875/Dewan-PersBeberkan-Ciri-Ciri-Berita-Hoax).

Kedudukan masyarakat pada akhirnya menjadi pihak yang harus berhati-hati dengan informasi yang beredar saat ini, padahal kebenaran atas suatu berita itu adalah tanggung jawab jurnalisme. Hal ini seperti yang dijelaskan oleh Bill Kovach dan Tom Rosenstial (2014, h. 33 34) yang mengatakan bahwa kewajiban dalam jurnalisme salah satunya adalah kebenaran.

"The desire that information be truthful is elemental. Since news is the material that people use to learn and think about the world beyond themselves, the most important quality it can possess is that it be usable and reliable. Will it rain tomorrow? Is there a traffic jam ahead? Did my team win? What did the President say? Truthfulness creates, in effect, the sense of security that grows from awareness and is at the essence of news".

Secara bebas dapat diartikan bahwa kebenaran atas berita adalah yang paling utama. Sejak berita menjadi bahan bagi manusia untuk belajar dan berfikir tentang belahan dunia lainnya yang tidak dapat diketahui oleh manusia, hal terpenting dari itu semua adalah bagaimana berita dapat digunakan dan diandalkan seperti akankah besok hujan? Apakah ada kemacetan? Apakah tim Saya menang? Apa yang dikatakan presiden? Kejujuran menciptakan rasa aman yang tumbuh dari kesadaran dan merupakan inti dari sebuah berita. 
Bill Kovach dan Tom Rosenstial (2014, h. 44) selanjutnya menjelaskan bahwa jurnalisme tidak mencari bentuk kebenaran absolut, filosofis atau ilmiahseperti persamaan kimia, melainkan kebenaran praktis dan fungsional yang memiliki arti kebenaran tersebut beroperasi untuk kebutuhan sehari-hari. Berdasarkan pendapat Bill Kovach dan Tom Rosenstialtersebut dapat disimpulkan bahwa esensi dari suatu berita adalah kebenaran yang mana atas kebenaran tersebut dijadikan dasar untuk belajar maupun berfikir. Walaupun kebenaran dari berita bukanlah kebenaran absolut, namun kebenaran tersebut dapat digunakan untuk memenuhi kebutuhan sehari-hari, oleh karenanya dengan berita manusia dapat mengetahui suatu kondisi atau keadaan yang sedang atau telah terjadi di beberapa tempat lainnya. Dengan kata lain manusia menjadi banyak tahu sehingga mempermudah baginya melakukan aktivitas.

Lalu apa yang dimaksud dengan kebenaran suatu berita? Kebenaran apa yang dicoba untuk disampaikan oleh para jurnalis melalui media massa? Apa yang dijelaskan Bill Kovach dan Tom Rosenstial di atas memang belum secara sempurna untuk menjawab apa yang dimaksud dengan kebenaran dari suatu berita, akan tetapi pendapat tersebut dapat dijadikan dasar untuk memperkuat argumentasi bahwa kebenaran dalam suatu berita bukanlah kebenaran yang bersifat absolut yang memiliki arti bahwa kebenaran itu bisa saja berubah-ubah. Kalau dengan demikian bagaimana masyarakat dapat mempercayai kebenaran suatu berita apabila informasi yang ada di dalam media massa tidak dapat dipertanggungjawabkan kepastian akan kebenarannya apabila kebenarannya dapat berubah-ubah karena yang sifatnya tidak absolut?

Antara berita dan kebenaran itu adalah dua hal yang berbeda. Kebanyakan orang di luar jurnalis dan malah banyak wartawan percaya jurnalisme menghasilkan kebenaran padahal berita dan kebenaran bukanlah hal yangsama, inilah pendapat dari Walter Lippmann (Ishwara, 2005, h. 24). Fakta yang disajikan wartawan terkadang menambah pada kebenaran, namun wartawan sering tidak mampu mengumpulkan cukup fakta dalam waktu yang diberikan untuk disediakan untuk dapat menceritakan kebenaran tentang subjek berita. Contoh yang dapat diambil mengenai berita dan kebenaran itu tidak selalu sinonim adalah apa yang benar dalam berita hari ini, bisa berubah dari hari kemudian. Narasumber atau pejabat pemerintah sering mengubah atau membantah pernyatannya sendiri yang sudah disiarkan media. Jadi waktu bisa mengubah perspektif dari sudut mana persitiwa itu dipandang (Ishwara, 2005, h. 24).

Penjelasan di atas memang dapat dikatakan ada benarnya karena memang apa yang disampaikan oleh media massa bisa saja sewaktu-waktu dapat berubah sehingga apa yang telah diberitakan sebelumnya menjadi lagi tidak sama dengan berita terbaru. Namun bukan berarti pendapat tersebut benar sepenuhnya, seperti apa yang telah dijelaskan oleh Bill Kovach dan Tom Rosenstial di atas adalah kebenaran berita bukanlah kebenaran yang absolut akan tetapi bagaimana suatu berita dapat digunakan bagi kepentingan manusia. Dalam hal ini dapat dipahami bahwa kebenaran yang dimaksud dalam berita adalah kebenaran yang memang sesuai dengan faktanya ketika berita itu dicari dan diperoleh. Maka dalam hal ini H. Eugene Goodwin (Ishwara, 2005, h. 25) berpendapat bahwa berita yang didapat oleh wartawan haruslah akurat yang mana jujur dalam mengumpulkan dan menyajikan fakta dan informasi, tidak bohong dan tidak menjiplak, "Being truth-fulll both in the gathering and presentation of facts and information, not lying, not plagiarizing".

Memang tidaklah mudah untuk memberikan kepercayaan kepada masyarakat atas kebenaran suatu berita apalagi kebenaran suatu berita tersebut tidak memiliki kebenaran absolut. Keberadaan berita-berita bohong sebenarnya bukanlah tanggung jawab masyarakat 
untuk menilainya karena pada dasarnya pers sendirilah yang bertanggung jawab atas kebenaran dari isi berita itu, hal ini dapat dilihat dalam Pasal 6 huruf c Undang-Undang Nomor 40 Tahun 1999 tentang Pers, "Mengembangkan pendapat umum berdasarkan informasi yang tepat, akurat dan benar." Selain itu pula berdasarkan Pasal 4 dalam Kode Etik Jurnalis disebutkan pula wartawan dilarang untuk melakukan pemberitaan bohong. Atas dasar dari dua hal tersebut saja sudah menjelaskan apabila pers itu memang berkewajiban untuk memberitakan berita yang benar bukan berita bohong. Di dalam Pasal 6 huruf e Undang-Undang Nomor 40 Tahun 1999 tentang Pers juga disebutkan bahwa pers memiliki peranan memperjuangkan keadilan dan kebenaran. Pers bekerja dengan berita yang disampaikan, memperjuangkan keadilan dan kebenaran tidak mungkin dilakukan dengan penyampaian berita bohong. Oleh karena itu atas dasar inilah pers harus menjalankan perannya ini dengan dasar penyampaian berita-berita benar tanpa ada kebohongan.

Namun satu hal yang harus dipahami oleh masyarakat kebenaran suatu berita adalah kebenaran nyata atas apa yang sedang terjadi terhadap suatu peristiwa tertentu. Pemahaman ini tidak terlepas dari arti sebuah kegiatan jurnalistik yang dimaksud dalam Pasal 1 angka 1 Undang-Undang Nomor 40 Tahun 1999 tentang Pers yaitu kegiatan jurnalistik meliputi mencari, memperoleh, memiliki, menyimpan, mengolah, dan menyampaikan informasi baik dalam bentuk tulisan, suara, gambar, suara dan gambar, serta data dan grafik maupun dalam bentuk lainnya dengan menggunakan media cetak, media elektronik, dan segala jenis saluran yang tersedia. Oleh karena itu terbentuknya kebenaran suatu berita tidak terlepas dari pelaksanaan Undang-Undang Nomor 40 Tahun 1999 tentang Pers. Selain itu juga berdasarkan Pasal 7 ayat 2 Undang-Undang Nomor 40 Tahun 1999 tentang Pers disebutkan bahwaWartawan memiliki dan menaati Kode Etik Jurnalistik. Wartawan yang juga merupakan bagian pers dalam melakukan kegiatan jurnalistik sesuai dengan Pasal 1 angka 1 Undang-Undang Nomor 40 Tahun 1999 tentang Pers haruslah juga mentaati Kode Etik Jurnalistik sebagai rujukan dalam berprofesi.

Kegiatan jurnalistik adalah suatu proses kegiatan yang dilakukan yang tujuannya untuk mencari kebenaran atas fakta yang tejadi di lapangan. Fakta tersebut disampaikan kepada masyarakat untuk menjadi suatu berita sehingga masyarakat dapat mengetahui apa yang terjadi atas fakta tersebut. Oleh karenanya seperti yang telah dijelaskan sebelumnya kebenaran suatu berita memiliki hubungan dengan kegiatan jurnalistik. Kegiatan jurnalistik dibagi menjadi 3 tahap, tahap pertama disebut dengan proses mendapatkan informasi yang terdiri dari mencari, memperoleh, memiliki, dan menyimpan. Tahap kedua disebut dengan mengolah informasi, dan tahap ketiga disebut dengan penyampaian informasi.

\section{Tahap Pertama: Mendapatkan Informasi}

Mendapatkan informasi adalah tahap pertama dalam kegiatan jurnalistik yang dilakukan melalui proses pencarian, perolehan dan dimiliki atas suatu informasi. Pasal 4 ayat 2 UndangUndang Nomor 40 Tahun 1999 tentang Pers menjadi salah satu dasar hukum bagi pers untuk mencari dan memperoleh informasi oleh karena itu hak ini dilindungi oleh undang-undang. Pada proses inilah awalnya kebenaran atas berita mulai terbentuk karena dilakukan dengan cara: 1. Observasi/mengamati

Observasi merupakan dasar dari pemberitaan yang baik. Deborah Potter (2009, h. 14) menyebutkan bahwa dengan cara observasi ini, seorang jurnalis dapat menjadi saksi atas 
kejadian yang terjadi lalu dapat menjelaskannya secara akurat. J. Tong menyebutkan (2015, h. 123), "Another method journalists usually adopt to understand the situations involved and make judgements is observation. Journalists even believe that observation should precede contacting experts, especially officials".

2. Penelitian

Para jurnalis cenderung mengumpulkan lebih banyak informasi daripada yang dapat mereka masukkan ke dalam suatu berita, namun informasi tersebut membantu mereka lebih memahami suatu permasalahan yang sedang diliput (Potter, 2009, h. 14).

3. Wawancara dari sumber pertama dan kedua

Para jurnalis dapat menggunakan sumber pertama dan kedua dalam membuat berita. Sumber pertama dapat dilakukan dengan cara mewawancarai dengan seseorang yang secara langsung mengalami suatu kejadian tertentu. Seorang jurnalis yang menjadi saksi mata juga dianggap sebagai sumber pertama. Sumber kedua dapat berupa laporan tertulis dari suatu dokumen asli (Potter, 2009, h. 16). Wawancara sedikit berbeda dengan percakapan biasa yang mana dalam wawancara setiap reporter menentukan pertanyaan yang akan ditanyakan (Potter, 2009, h. 17). Tim Holmes, Sara Hadwin, dkk (2014, h. 35) menyebutkan “Interview is a chance to get first-hand accounts. Colorful background and interesting quotes-all the things that mark the difference between a second-rate story and something that people will want to read. Like developing writing style, interview is intensively personal". Lynette Sheridan Burns juga menjelaskan wawancara memiliki peran penting dalam kegiatan jurnalistik hal ini dikarenakan wawancara dapat memberikan kepada para jurnalis jawaban cepat atas beberapa pertanyaan yang spesifik terhadap topik yang tidak diketahui sebelumnya (2012, h. 91).

Tidak hanya sampai disitu, untuk melihat kebenaran atas informasi yang didapat maka pemeriksaan ulang harus dilakukan. Hal ini bertujuan untuk memastikan akurasi informasi. Para jurnalis pasti membuat kesalahan, namun hal tersebut harus diminalisir. Sebagai contoh media cetak harian The Oregonian. Editor media cetak The Oregonian pernah menemukan kesalahan-kesalahan yang dilakukan dalam melakukan pemberitaan yang diantaranya (Potter, 2009, h. 21):

1. Berita menjadi salah karena menyimpan informasi hanya dengan mengandalkan ingatan

2. Informasi yang dicari hingga disimpan sudah bercampur dengan asumsi

3. Informasi yang dicari diambil dari informasi pihak kedua

Ke-3 alasan di ataslah yang dapat menjadi kesalahan dalam isi berita, karena suatu informasi yang disimpan hanya berlandaskan dengan ingatan sangat rentan hilang. Ingatan manusia sangat terbatas, oleh karenanya Deborah Potter menyarankan agar kepada jurnalis ketika melakukan pencarian informasi sebaiknya melakukan pencatatan baik secara tertulis atau rekaman. Informasi yang dicari hingga disimpan jangan dicampurkan dengan asumsi pencari berita ataupun asumsi dari sumber berita, hal ini akan menimbulkan persepsi baru atas objektivitas kebenaran berita yang akan disampaikan. Berikutnya adalah pengambilan informasi dari pihak kedua. Sebelumnya telah dijelaskan bahwa sumber yang dimintai keterangan haruslah berdasarkan dari sumber pertama ataupun sumber kedua seperti informasi tertulis yang berasal dari dokumen asli, bukan informan yang tahu informasi dari pihak lain. Informasi seperti ini bisa menjadi berbeda karena informasi yang didapat oleh pihak kedua tersebut bisa saja berkurang atau berlebih, oleh karenanya tidak disarankan mengambil informasi dari pihak kedua tersebut. 
Oleh karena itu berdasarkan Pasal 2 Peraturan Dewan Pers Nomor:6/Peraturan-DP/V/2008 tentang Pengesahan Surat Keputusan Dewan Pers Nomor 03/SK-DP/III/2006 tentang Kode Etik Jurnalistik Sebagai Peraturan Dewan Pers disebutkan bahwa wartawan Indonesia harus menempuh cara-cara yang professional dalam melaksanakan tugas jurnalistik. Penafsiran atas pasal ini dikaitkan dengan tahap mendapatkan informasi adalah ketika jurnalis atau wartawan melaksanakan tugas jurnalistik seperti observasi, penelitian maupun wawancara haruslah dilakukan dengan cara professional seperti:

1. Menunjukkan identitas diri kepada narasumber

2. Menghormati hak privasi

3. Tidak menyuap

4. Menghasilkan berita yang faktual dan jelas sumbernya

5. Rekayasa pengambilan dan pemuatan atau penyiaran gambar, foto, suara dilengkapi dengan keterangan tentang sumber dan ditampilkan secara berimbang

6. Menghormati pengalaman traumatik narasumber dalam penyajian gambar, foto, suara

7. Tidak melakukan plagiat, termasuk menyatakan hasil liputan wartawan lain sebagai karya sendiri

8. Penggunaan cara-cara tertentu dapat dipertimbangkan untuk peliputan berita investigasi bagi kepentingan publik.

Menjaga professional wartawan seperti yang dijelaskan di atas juga dipengaruhi dengan tingkah laku wartawan itu sendiri oleh karena itu sesuai dengan Pasal 6 Peraturan Dewan Pers Nomor: 6/Peraturan-DP/V/2008 tentang Pengesahan Surat Keputusan Dewan Pers Nomor 03/SK-DP/III/2006 tentang Kode Etik Jurnalistik Sebagai Peraturan Dewan Pers disebutkan bahwa wartawan Indonesia tidak menyalahgunakan profesi dan tidak menerima suap. Tafsiran atas pasal tersebut adalah:

1. Menyalahgunakan profesi adalah segala tindakan yang mengambil keuntungan pribadi atas informasi yang diperoleh saat bertugas sebelum informasi tersebut menjadi pengetahuan umum.

2. Suap adalah segala pemberian dalam bentuk uang, benda atau fasilitas dari pihak lain yang mempengaruhi independensi.

Pada saat mencari informasi kepada narasumber berita, wartawan Indonesia menghormati hak narasumber tentang kehidupan pribadinya, kecuali untuk kepentingan publik, hal ini sesuai dalam Pasal 9 Peraturan Dewan Pers Nomor:6/Peraturan-DP/V/2008 tentang Pengesahan Surat Keputusan Dewan Pers Nomor 03/SK-DP/III/2006 tentang Kode Etik Jurnalistik Sebagai Peraturan Dewan Pers. Tafsiran atas pasal ini adalah:

1. Menghormati hak narasumber adalah sikap menahan diri dan berhati-hati

2. Kehidupan pribadi adalah segala segi kehidupan seseorang dan keluarganya selain yang terkait dengan kepentingan publik

\section{Tahap Kedua: Mengolah Informasi}

Pengolahan suatu informasi menjadi penting karena pada tahap ini dilakukannya langkah penyusunan semua informasi yang telah disimpan. Undang-Undang Nomor 40 Tahun 1999 tentang Pers tidak menjelaskan maksud arti kata 'mengolah' namun secara harfiah kata 'mengolah' berarti mengerjakan, mengusahakan sesuatu supaya menjadi lain atau lebih sempurna. Dari arti kata tersebut dapat dimengerti bahwa informasi yang sudah disimpan tersebut harus dibuat menjadi sempurna. Pengolahan pastinya melalui proses editinginformasi, dalam proses ini akan terlihat kembali adanya kerancuan-kerancuan informasi timbul seperti data berita kurang lengkap atau informasi dari sumber pertama atau kedua yang kurang lengkap 
dan sebagainya. Pada tahap inilah segalanya akan ditentukan apakah akan dilakukan kembali atau tidak suatu pencarian informasi.

Mengolah informasi dapat juga diistilahkan dengan editing processdi mana editor bekerja untuk memastikan bahwa informasi yang akan diterbitkan dalam suatu berita dibuat dalam bahasa dan tampilan yang baik, akurat, sempurna dan seimbang (Deborah Potter, 2009, h. 30). Tahap kedua ini merupakan proses sangat penting karena setelah lewat dalam tahap ini maka tahap selanjutnya hanyalah tinggal untuk diterbitkan kepada masyarakat. Oleh karenanya tahap pengolahan informasi atau editingberperan besar dalam memberikan kebenaran berita itu karena adanya tindakan cek ulang atas setiap informasi yang ada.

Penyimpanan informasi dilakukan seperti tahap pertama dilakukan untuk penyempurnaan isi berita sebelum disampaikan kepada publik, oleh karenanya hal ini hanya bertujuan melengkapi informasi-informasi yang kurang saja. Intinya pengolahan informasi adalah proses dimana penyaringan informasi yang telah disimpan oleh jurnalis. Banyaknya informasi yang telah disimpan tidak akan sama banyaknya dengan berita yang akan disampaikan karena seluruh informasi tersebut haruslah dirangkum menjadi berita yang singkat dan padat tanpa meninggalkan esensi dari kebenaran fakta kejadiannya.

Mengolah informasi sejalan dengan Pasal 3 Peraturan Dewan Pers Nomor:6/PeraturanDP/V/2008 tentang Pengesahan Surat Keputusan Dewan Pers Nomor 03/SK-DP/III/2006 tentang Kode Etik Jurnalistik Sebagai Peraturan Dewan Pers yang mana disebutkan bahwa Wartawan Indonesia selalu menguji informasi, memberitakan secara berimbang, tidak mencampurkan fakta dan opini yang menghakimi, serta menerapkan asas praduga tak bersalah. Tafsiran atas pasal ini disebutkan yang salah satunya adalah wartawan selalu menguji informasi berarti melakukan check and recheck tentang kebenaran informasi itu. Selain itu juga berimbang dalam memberikan ruang atau waktu pemberitaan kepada masing-masing pihak secara proporsional, opini yang menghakimi adalah pendapat pribadi wartawan. Hal ini berbeda dengan opini interpretatif, yaitu pendapat yang berupa interpretasi wartawan atas fakta. Asas praduga tak bersalah adalah prinsip tidak menghakimi seseorang.

Berdasarkan Pasal 5 ayat 1 Undang-Undang Nomor 40 Tahun 1999 tentang Pers disebutkan bahwa pers nasional berkewajiban memberitakan peristiwa dan opini dengan menghormati norma-norma agama dan rasa kesusilaan masyarakat serta asas praduga tak bersalah. Pasal ini memiliki esensi bahwa setiap berita yang akan disampaikan ke masyarakat tidaklah boleh bersifat subjektif namun objektif, frasa 'asas praduga tak bersalah' menunjukkan bahwa peristiwa apapun yang menjadi objek berita tidak boleh diberitakan sesuai keinginan dari perusahaan pers namun sesuai dengan apa yang terjadi tanpa ada justifikasi apapun. Oleh karenanya berdasarkan Pasal 5 ayat 1 Undang-Undang Nomor 40 Tahun 1999 tentang Pers ini akan menjadi panduan bagi insan pers setiap berita yang akan disampaikan haruslah diolah dengan baik agar terhindar dari adanya subjektifitas penyamapain berita atau adanya justifikasi peristiwa yang menjadi objek berita. agar ke-3 ini dengan sendirinya mengarahkan kepada insan pers.

Asas praduga tak/tidak bersalah memiliki arti seorang tersangka atau terdakwa tidak boleh dinyatakan bersalah sebelum ada putusan pengadilan yang berkekuatan hukum mengikat (in kracht van gewijsde). Asas praduga tidak bersalah adalah pengarahan bagi aparat penegak hukum tentang bagaimana mereka harus bertindak lebih lanjut dan mengesampingkan praduga bersalah dalam tingkah lagu mereka terhadap tersangka (Supardi, 2018, h. 105). Apabila 
merujuk pada makna asas praduga tidak bersalah tersebut ke dalam pengolahan informasi maka peristiwa atau fakta apapun yang menjadi objek pemberitaan tidak dapat dilakukan penilaian tertentu atas fakta atau peristiwa apalagi peristiwa tersebut mengarah kepada seseorang. Selayaknya peristiwa itu apa yang diambil maka itulah yang dikeluarkan hal ini seperti $\mathrm{a}=\mathrm{a}$ tidak dapat $\mathrm{a}=\mathrm{b}$.

Pers yang memiliki peranan pengawasan, kritik, koreksi, dan saran yang berkaitan dengan kepentingan umum (Pasal 6 huruf d Undang-Undang Nomor 40 tahun 1999 tentan Pers) melalui produknya (berita) tidak lepas dari proses pengolahan informasi yang benar. Pengawasan, kritik, koreksi dan saran hanya dilakukan oleh pihak-pihak yang memiliki dasar kebenaran, tahu membedakan mana yang salah dan mana yang benar. Pengawasan, kritik, koreksi, dan saran tersebut dilakukan dengan sebuah berita oleh pers, oleh karena itu pengolahan informasi ini tidak boleh mendegradasi dari makna sesungguhnya atas fakta/peristiwa yang ada dengan cara penerapan asas praduga tak bersalah.

\section{Tahap Ketiga: Penyampaian Informasi}

Pada tahap ketiga ini dapat diistilahkan 'informasi jadi' yang akan diterbitkan baik melalui media cetak ataupun elektronik, karena tahap pengolahan informasi sudah terlewati. Tidaklah mudah untuk melakukan penyampaian informasi, karena secara tersirat di dalam Pasal 1 angka 1 Undang-Undang Nomor 40 Tahun 1999 tentang Pers memberikan tanggung jawab besar kepada pers untuk memberikan informasi atau berita yang benar kepada masyarakat. Karena apabila berita itu sudah disampaikan kepada masyarakat maka berita yang disampaikan merupakan suatu kebenaran.

Penyampaian informasi adalah tahap menentukan kapan informasi itu untuk dijadikan berita. Setelah berita disampaikan maka disitulah masyarakat akan mengkonsumsi berita tersebut dan menganggap berita itu yang dibaca adalah berita benar. Anggapan masyarakat yang mendasarkan berita yang ada di dalam media massa adalah kebenaran tidak dapat disalahkan karena berita tersebut secara prinsipnya memang terbentuk dari proses yang penuh dengan kehati-hatian sesuai dengan fakta proses kegiatan jurnalistik.

Berdasarkan Pasal 5 Peraturan Dewan Pers Nomor:6/Peraturan-DP/V/2008 tentang Pengesahan Surat Keputusan Dewan Pers Nomor 03/SK-DP/III/2006 tentang Kode Etik Jurnalistik Sebagai Peraturan Dewan Pers disebutkan bahwa wartawan Indonesia tidak menyebutkan dan menyiarkan identitas korban kejahatan susila dan tidak menyebutkan identitas anak yang menjadi pelaku kejahatan. Tafsiran atas pasal ini adalah identitas adalah semua data dan informasi yang menyangkut diri seseorang yang memudahkan orang lain untuk melacak. Anak adalah seorang yang berusia kurang dari 16 tahun dan belum menikah.

Kemudian di Pasal 8 Peraturan Dewan Pers Nomor:6/Peraturan-DP/V/2008 tentang Pengesahan Surat Keputusan Dewan Pers Nomor 03/SK-DP/III/2006 tentang Kode Etik Jurnalistik Sebagai Peraturan Dewan Pers disebutkan bahwa Wartawan Indonesia tidak menulis atau menyiarkan berita berdasarkan prasangka atau diskriminasi terhadap seseorang atas dasar perbedaan suku, ras, warna kulit, agama, jenis kelamin, dan bahasa serta tidak merendahkan martabat orang lemah, miskin, sakit, cacat jiwa atau cacat jasmani. Tafsiran atas pasal ini adalah:

1. Prasangka adalah anggapan yang kurang baik mengenai sesuatu sebelum mengetahui secara jelas 
2. Diskriminasi adalah pembedaan perlakuan.

Pasal 6 huruf c Undang-Undang Nomor 40 Tahun 1999 tentang Pers meyebutkan "Mengembangkan pendapat umum berdasarkan informasi yang tepat, akurat, dan benar", dasar inilah yang menjadi salah satu dasar bahwa informasi yang dibentuk dalam suatu berita yang dilakukan oleh media massa itu adalah akurat dan benar. Oleh karena itu anggapan masnyarakat atas berita yang disampaikan oleh media massa sebagai bentuk dari kebenaran bukanlah suatu kesalahan.

Di dalam Pasal 1 Peraturan Dewan Pers Nomor:6/Peraturan-DP/V/2008 tentang Pengesahan Surat Keputusan Dewan Pers Nomor 03/SK-DP/III/2006 tentang Kode Etik Jurnalistik Sebagai Peraturan Dewan Pers, disebutkan bahwa "Wartawan Indonesia bersikap independen, menghasilkan berita yang akurat, berimbang dan tidak beritikad buruk". Frasa "menghasilkan berita yang akurat" memilliki penafsiran bahwa berita tersebut dipercaya benar sesuai keadaan objektif ketika peristiwa terjadi. 'Benar' memiliki arti sesuai sebagaimana adanya atau dapat dipercaya (cocok dengan keadaan yang sesungguhnya) (Pusat Bahasa Departemen Pendidikan Nasional, 2008, h. 172), 'objektif' memiliki arti mengenai keadaan yang sebenarnya tanpa dipengaruhi pendapat atau pandangan pribadi (Pusat Bahasa Departemen Pendidikan Nasional, 2008, h. 1014).

Berita yang disampaikan oleh media massa sebenarnya tidak boleh melanggar apa yang telah ditentukan dalam Pasal 4Peraturan Dewan Pers Nomor:6/Peraturan-DP/V/2008 tentang Pengesahan Surat Keputusan Dewan Pers Nomor 03/SK-DP/III/2006 tentang Kode Etik Jurnalistik Sebagai Peraturan Dewan Persdisebutkan bahwa wartawan Indonesia tidak membuat berita bohong, fitnah, sadis, dan cabul. Penafsirannya adalah:

1. Bohong berarti sesuatu yang sudah diketahui sebelumnya oleh wartawan sebagai hal yang tidak sesuai dengan fakta yang terjadi

2. Fitnah berarti tuduhan tanpa dasar yang dilakukan secara sengaja dengan niat buruk

3. Sadis berarti kejam dan tidak mengenal belas kasihan

4. Cabul berarti penggambaran tingkah laku secara erotis dengan foto, gambar, suara, grafis atau tulisan yang semata-mata untuk membangkitkan nafsu birahi.

5. Dalam penyiaran gambar dan suara dari arsip, wartawan mencantumkan waktu pengambilan gambar dan suara.

Pers pada prinsipnya memiliki tanggung jawab terhadap kebenaran atas berita yang akan disampaikan karena adanya kewajiban melasanakan kegiatan jurnalistik. Tanpa adanya kewajiban ini, maka pers dapat saja melakukan suatu pemberitaan yang merugikan orang lain seolah-olah tanpa adanya beban tanggung jawab atas kebenaran berita tersebut.Jawaban atas pertanyaan sebelumnya terkait dengan kebenaran suatu berita, maka jawabannya adalah kebenaran yang sesuai dengan fakta atas kejadian peristiwa tertentu yang akan dijadikan sebuah berita. Fakta atas peristiwa tersebut diperoleh seorang jurnalis dari berbagai sumber. Tidak ada permasalahan sumber tersebut diambil dari sumber kedua asalkan informasinya tidak kontradiktif dengan sumber pertama, oleh karenanya perolehan informasi yang hanya berdasarkan informasi kedua harus dihindari karena belum tentu sesuai dengan fakta atas kejadian peristiwa yang akan dijadikan berita.

Penarikan informasi yang kemudian diolah dari seorang jurnalis untuk menjadi suatu berita haruslah sesuai dengan fakta atas peristiwa tertentu, peristiwa tersebut tidak boleh dicampuradukkan dengan pendapat si jurnalis. Bahkan informan yang akan dijadikan sumber 
informasi sendiri pun tidak dapat dijadikan seorang informan apabila ia tidak mengetahui suatu fakta kejadian peristiwa tertentu sesuai dengan apa yang ia lihat, dengar atau dialaminya sendiri. Oleh karenanya informan pun yang kedudukannya dijadikan sebagai sumber berita harus benarbenar dipilih atas kemampuan pengetahuannya atas kejadian peristiwa tertentu yang dijadikan suatu berita. Selanjutnya, seorang jurnalis juga tidak dapat mencampur adukkan opini atau anggapannya atas informasi yang telah diperolehnya sekalipun informasi tersebut berasal dari sumber pertama yang secara langsung mengalami atas kejadian suatu peristiwa tertentu yang akan dijadikan suatu berita. Data atau informasi yang didapat seorang jurnalis dari lapangan, maka itulah data atau informasi sesungguhnya.

Lalu bagaimana apabila terdapat beberapa kantor berita yang memberitakan suatu peristiwa tertentu yang informasi di dalamnya berbeda-beda? Atas permasalahan ini pasti ada dua kemungkinan, media massa mendapatkan informasinya telah salah dalam melakukan kegiatan jurnalistik atau memang pengambilan data atau informasinya di waktu yang berbeda, karena tidak mungkin ada satu peristiwa yang kejadiannya sama namun informasi yang terkandung di dalamnya berbeda.

Sebagai contoh, jurnalis A dari media massa XYZ mendatangi tempat terjadinya kebakaran pada pukul 14.00 WIB, jurnalis B dari media massa ABC juga mendatangi tempat kejadian yang sama pada pukul 14.00 WIB. Jurnalis A melakukan wawancara dengan korban kebakaran serta dari pihak kepolisian setempat yang telah melakukan investigasi, sedangkan jurnalis B mewawancarai seseorang yang sama sekali bukan korban dan juga bukan warga yang tinggal di sekitar tempat kejadian. Setelah mendapatkan data dari tempat kejadian, jurnalis A dan B kembali ke perusahaan media massa di mana mereka bekerja dan melakukan pengolahan informasi lalu diterbitkan baik secara online, cetak maupun elektronik. Dapat dipastikan informasi dari media massa di mana jurnalis A dan B bekerja berbeda, hal ini dikarenakan karena informasi yang dijadikan sumber data dalam menceritakan kejadian kebakaran berbeda

Contoh kedua terkait dengan pengambilan data atau informasi di waktu yang berbeda. Jurnalis A dari media massa XYZ mendatangi tempat terjadinya kebakaran pada pukul 14.00 WIB. Informasi yang didapat atas terjadinya kebakaran mengenai adanya korban meninggal dunia sebanyak 20 orang. Setelah mendapatkan informasi tersebut, jurnalis itu kembali ke kantor berita untuk melakukan pengolahan informasi.Seorang jurnalis B dari media massa ABC mendatangi tempat terjadinya kebakaran yang sama pada pukul 15.00 WIB. Informasi yang didapat akibat kebakaran tersebut adalah adanya korban meninggal dunia sebanyak 34 orang. Informasi atau data antara jurnalis A dan B sudah berbeda, dan tentu saja informasi yang akan dijadikan berita sesuai dengan informasi yang diperoleh sebelumnya. Lalu apakah ini menjadi permasalahan? Sebenarnya ini bukanlah permasalahan asalkan informasi yang akan dijadikan berita lalu disampaikan kepada publik sesuai dengan faktanya. Sesuai dengan faktanya adalah kapan berita itu diperoleh. Dari contoh, jurnalis A mendapatkan informasi korban sebanyak 20 orang, maka berita yang disampaikan adalah korban 20 orang tersebut berdasarkan fakta yang diperoleh pada pukul 14.00 WIB. Sedangkan jurnalis B mendapatkan informasi korban jiwa sebanyak 34 orang pada pukul 15.00 WIB. Maka dengan demikian, berita yang disampaikan oleh media massa tidak dapat lepas dari kapan informasi tersebut diperoleh.

Bahwa perbedaan isi informasi atas berita yang disampaikan kepada masyarakat yang menjadi permasalahan adalah apabila informasi yang ada di dalam berita tersebut tidak berdasarkan sumber yang dapat dipercaya atau informasi itu sama sekali tidak ada sehingga 
dianggap ada atau informasi tersebut sama sekali tidak sesuai dengan fakta. Pentingnya menjalankan kegiatan jurnalistik sesuai yang ditentukan dalam Pasal 1 angka 1 UndangUndang Nomor 40 Tahun 1999 tentang Pers “...mencari, memperoleh, memiliki, menyimpan, mengolah, dan menyampaikan informasi.." atau yang sering disingkat dengan $6 \mathrm{M}$ adalah menjadi dalil utama untuk menyebut apakah informasi yang disampaikan oleh media massa mengandung kebenaran atau tidak.

\section{KESIMPULAN}

Berita yang dikatakan memiliki kebenaran adalah berita yang sesuai dengan fakta atas kejadian peristiwa tertentu yang akan dijadikan sebuah berita. Fakta atas kejadian yang dimaksud haruslah diolah dan disampaikan sesuai dengan isi Pasal 1 angka Undang-Undang Nomor 40 Tahun 1999 tentang Pers yaitu "Pers adalah lembaga sosial dan wahana komunikasi massa yang melaksanakan kegiatan jurnalistik meliputi mencari, memperoleh, memiliki, menyimpan, mengolah, dan menyampaikan informasi baik dalam bentuk tulisan, suara, gambar, suara dan gambar, serta data dan grafik maupun dalam bentuk lainnya dengan menggunakan media cetak, media elektronik, dan segala jenis saluran".Teks 'mencari, memperoleh, memiliki, menyimpan, mengolah, dan menyampaikan informasi' adalah teks yang menunjukkan suatu proses di mana suatu informasi yang akan dijadikan berita haruslah didapatkan terlebih dahulu, diolah kemudian disampaikan. Informasi didapat dengan cara; observasi, penelitian dan wawancara. Informasi diolah dengan cara cek ulang dana tau editingatas informasi yang telah didapat. Kemudian informasi disampaikan melalui media cetak, online dan atau elektronik setelah melewati tahap pertama dan kedua sebelumnya. Apabila tahap pertama dan kedua terlewati maka berita tersebut sudah dapat dikatakan kebenaran. Kebenaran pun bukan kebenaran absolut karena kebenaran dari berita adalah kebenaran yang sesuai dengan fakta atas kejadian peristiwa tertentu yang dijadikan sebuah berita. Di dalam Pasal 1 Peraturan Dewan Pers Nomor:6/Peraturan-DP/V/2008 tentang Pengesahan Surat Keputusan Dewan Pers Nomor 03/SK-DP/III/2006 tentang Kode Etik Jurnalistik Sebagai Peraturan Dewan Pers, disebutkan bahwa "wartawan Indonesia bersikap independen, menghasilkan berita yang akurat, berimbang dan tidak beritikad baik". Pasal 4 Peraturan Dewan Pers Nomor:6/Peraturan-DP/V/2008 tentang Pengesahan Surat Keputusan Dewan Pers Nomor 03/SK-DP/III/2006 tentang Kode Etik Jurnalistik Sebagai Peraturan Dewan Pers disebutkan bahwa wartawan Indonesia tidak membuat berita bohong, fitnah, sadis dan cabul. Dengan demikian jelaslah bahwa pers berkewajiban untuk menghasilkan suatu berita benar sesuai dengan kenyataannya yang didasarkan $6 \mathrm{M}$.

\section{SARAN}

Undang-Undang Nomor 40 Tahun 1999 tentang Pers dan Peraturan Dewan Pers Nomor:6/Peraturan-DP/V/2008 tentang Pengesahan Surat Keputusan Dewan Pers Nomor 03/SK-DP/III/2006 tentang Kode Etik Jurnalistik Sebagai Peraturan Dewan Pers bukanlah hanya sekedar penghias sebagai pelengkap bagi insan pers akan tetapi sebagai instrumen dalam mempertahankan kebenaran berita yang disampaikan. Masyarakat bukanlah objek yang hanya menjadi target bagi pers akan tetapi sebagai subjek yang kedudukannya berhak mendapatkan informasi-informasi yang bermanfaat. Oleh karena itu kehadiran Undang-Undang Nomor 40 Tahun 1999 tentang Pers dan Peraturan Dewan Pers Nomor:6/Peraturan-DP/V/2008 tentang 
Pengesahan Surat Keputusan Dewan Pers Nomor 03/SK-DP/III/2006 tentang Kode Etik Jurnalistik Sebagai Peraturan Dewan Pers sebagai sarana membentuk suatu kebenaran atas berita. 


\section{DAFTAR PUSTAKA}

Ali, Zainuddin. (2011). Metode Penelitian Hukum, cetakan ke-3. Jakarta: Penerbit Sinar Grafika. AR, M. Fikri. (2016). Jurnalisme Kontekstual (Rahasia Menjadi Jurnalis di Era New Media). Malang: Universitas Brawijaya Press.

Bill Kovach \& Tom Rosenstiel. (2014). The Elements of Journalism, $3^{\text {rd }}$ edition. New York: Three Rivers Press.

Burns, Lynette Sheridan. (2013). Understanding Journalism. California: Sage.

Dedy. (2017). Dewan Pers Beberkan Ciri-Ciri Berota Hoax. Diakses pada tanggal 25 Januari 2020, melalui https://dewanpers.or.id/berita/detail/875/Dewan-Pers-Beberkan-Ciri-CiriBerita-Hoax.

Fachruddin, Andi. (2017). Dasar-Dasar Produksi Televisi: Produksi Berita, Feature, Laporan Investigasi, Dokumenter dan Teknik Editing, edisi ke-4. Jakarta: Kencana.

Harisman. (2020). Perlindungan Hukum Bagi Guru Dalam Menjalankan Tugas Pendidikan Dan Pengajara, Jurnal Hukum De Lega Lata, 5(1), 85.

Hartono, C. F. G. Sunaryati. (1994). Penelitian Hukum Di Indonesia Pada Akhir Abad Ke-20. Bandung: Penerbit Alumni.

Holmes, Tim. Sara Hadwin. Glyn Mottershead. (2014). The $21^{\text {st }}$ Century Journalism Handbook: Essential Skills for The Modern Journalist. London: Routledge.

Ibrahim, Johnny, (2008). Teori dan Metodologi Penelitian Hukum Normatif. Surabaya: Bayumedia.

Ishwara, Luwi. (2005). Catatan-catatan Jurnalisme Dasar. Jakarta: PT. Kompas Media Nusantara.

Juditha. Christianty. (2013). Akurasi Berita dalam Jurnalisme Online, Jurnal Pekommas, 16(3), 146.

Margianto, J. Heru \& Asep Syaefullah. (2014). Media Online: Antara Pembaca, Laba dan Etika. Problematika Praktik Jurnalisme Online di Indonesia. Jakarta: Aji Indonesia.

Marzuki, Peter Mahmud. (2006). Penelitian Hukum, cetakan ke-2. Jakarta: Kencana.

Muslimin, Khoirul. (2019). Jurnalistik Dasar: Jurus Jitu Menulis Berita, Feature Biografi, Artikel Populer dan Editorial. Yogyakarta: UNISNU.

Potter, Debora. (2009). Handbook of Independent Journalism. Florida: Orange Grove Texts Plus.

Pusat Bahasa Departemen Pendidikan Indonesia. (2008). Kamus Besar Bahasa Indonesia. Jakarta: Gramedia Pustaka Utama.

Rahmi, Atikah. (2019). Pemenuhan Restitusi Kompensasi Sebagai Bentuk Perlindungan Bagi Korban Kejahatan Seksual Dalam Sistem Hukum di Indonesia, Jurnal Hukum De Lega Lata, 4(2), 145.

Ramadhani, Rahmat. (2017). Jaminan Kepastian Hukum Yang Terkandung Dalam Sertipikat Hak Atas Tanah, Jurnal Hukum De Lega Lata, 2 (1), 142.

Ridlo, Muhammad. (2018). Hati-Hati dengan Berita Bohong. Diakses pada tanggal 25 Januari 2020, melalui https://dewanpers.or.id/publikasi/opini_detail/166/Hatihati_Dengan_Berita_Bohong. 
Rizki, Juni Wati Sri. (2016). Kepemilikan Media dan Ideologi Pemberitaan. Sleman: CV. Budi Utama.

Ryfe, David. M. (2016). Journalism and The Public. Cambridge: Polity.

Supardi. (2018). Perampasan Harta Hasil Korupsi: Perspektif Hukum Pidana Yang Berkeadilan. Jakarta: Kencana.

Tahrun, Houtman \& Muhammad Nasir. (2019). Keterampilan Pers dan Jurnalistik Berwawasan Jender. Sleman: CV. Budi Utama.

Tong, J. (2015). Investigate Journalism, Environmental Problems and Modernisation in China. New York: Palgrave Macmillan.

Wibowo, Wahyu. (2006). Menuju Jurnalisme Beretika: Peran Bahasa, Bisnis dan Politik di Era Mondial. Jakarta: PT. Kompas Media Nusantara.

Yudantara, Ketut Gede. (2006).Mengubah Ketidakpastian Menjadi Peluang. Jakarta: PT. Elex Media Komputindo. 